\title{
A GEOECONOMIA DA PRODUÇÃO DE SOJA NO SUL DO MARANHÃO: CARACTERÍSTICAS SOCIAIS E TERRITORIAIS
}

\author{
GEOECONOMICS OF SOYBEAN PRODUCTION IN THE SOUTH OF \\ MARANHÃO: SOCIAL AND TERRITORIAL CHARACTERISTICS
}

\section{LA GEOECONOMÍA DE LA PRODUCCIÓN DE SOJA EN EL SUR DE MARANHÃO: CARACTERÍSTICAS SOCIALES Y TERRITORIALES}

\section{Roberto César Costa Cunha}

Graduação em Geografia pela Universidade Federal de Manaus. Mestre em Geografia pela Universidade Federal de Santa Catarina. Professor substituto do Departamento de Geociências da Universidade Federal de Santa Catarina.

Campus universitário Reitor João David Ferreira Lima - Trindade. CEP: 88.040-900 - Florianópolis - SC. E-mail: robertoujsma@hotmail.com

\section{Carlos José Espíndola}

Graduação em Geografia pela Universidade Federal de Santa Catarina. Doutor em Geografia Humana pela Universidade de São Paulo. Professor associado do Departamento de Geociências da UFSC.

Campus universitário Reitor João David Ferreira Lima - Trindade. CEP: 88.040-900 - Florianópolis - SC. E-mail: cje@cfh.ufsc.br

\section{RESUMO}

O objetivo do presente texto é apresentar as características territoriais e sociais gestadas da expansão da cadeia produtiva da soja no sul do Maranhão na esteira do aumento da divisão social do trabalho. No primeiro momento de produção de soja no Maranhão, os pioneiros mantinham um aparente controle administrativo, financeiro e moral de toda a unidade produtiva. Atualmente, a estrutura administrativa das unidades produtivas da cadeia de produção da soja no sul do Maranhão divide-se em quatro MRECs. Nas MRECs 1 e 2, localizam-se fazendas das empresas de origem recente; há gestão empresarial; são contratados mais trabalhadores especializados; e há, em média, 10.000 hectares de área de lavoura. Nas MRECs 3 e 4, situam-se as empresas fundadas por pioneiros; é incorporada menos mão de obra especializada; e a área média de lavoura é de 3.000 hectares. Contudo, ambos os grupos de empresas são administrados por controle familiar direto e com relações paternalistas.

Palavras-chave: Divisão do trabalho. Dinâmica territorial. Relações sociais. Soja. Sul do Maranhão.

\section{ABSTRACT}

The paper's aim is to present social and territorial characteristics gestated through the productive chain expansion of soy, in southern Maranhão, in the wake of social division increase of labor. In the first moment of soybean production, in Maranhão, pioneers 
kept an apparent administrative, financial and moral control of the entire production unit. Currently, the administrative structure of production units of soybean production chain, in southern Maranhão, is divided into four MRECs. In MRECs 1 and 2, there are located farms of recent origin companies, there is business management, more skilled workers are being hired and there is an average of 10,000 hectares of crop area. In MRECs 3 and 4, there are companies founded by pioneers, less labor-skilled labor is being incorporated and the average farming area is 3,000 hectares. However, both groups of companies are administered by direct family control and paternalistic relationships.

Keywords: Labor division. Territorial dynamics. Social relations. Soy. Southern Maranhão.

\section{RESUMEN}

El objetivo de este trabajo es presentar las características territoriales y sociales generadas por la expansión de la cadena productiva de la soja en el sur de Maranhão, en la estela de la creciente división social del trabajo. Al comienzo de la producción de soja en Maranhão, los pioneros mantuvieron un control administrativo, financiero y moral aparente de toda la unidad de producción. Actualmente, la estructura administrativa de las unidades productivas de la cadena de producción de soja en el sur de Maranhão se divide en cuatro MRECs: MRECs 1 y 2, ubicadas en las granjas de las empresas de origen reciente, tienen gestión empresarial y contratan a más trabajadores calificados, tienen un promedio de 10.000 hectáreas de superficie de cultivo; en las MRECs 3 y 4 se ubican las empresas fundadas por los pioneros, poseen menos mano de obra especializada y tienen una zona de cría promedio de 3000 hectáreas. Sin embargo, ambos grupos de empresas son administradas por el control directo de la família y con relaciones paternalistas.

Palabras clave: División del trabajo. Dinámicas territoriales. Relaciones sociales. Soja. Sur de Maranhão 


\section{INTRODUÇÃO}

O processo de modernização da agricultura brasileira, marcado pelo forte aprofundamento da dinâmica capitalista, comprova que a agricultura é um ramo especializado da produção incorporada na divisão social do trabalho e que agrega novas características territoriais e sociais, tanto a montante quanto a jusante das atividades, ou seja, do pré à pós-porteira das fazendas ${ }^{1}$. Sampaio, Broietti e Medeiros (2005) assinalam, entre outros elementos, que esse processo caracteriza-se por: (i) alargamento da integração da agricultura e indústria; (ii) crescente demanda de novas técnicas e instrumentos de produção que aumentam tanto a produtividade da terra quanto da mão de obra; (iii) aumento da participação das exportações mundiais; (iv) inserção de novos centros produtores, com tecnologia de ponta e escalas ampliadas de produção, sobretudo em áreas de fronteiras agrícolas; (v) reestruturação acirrada das relações sociais entre setores da produção agrícola (produtores rurais, comerciantes, agroindústria, indústria, trabalhadores, etc.).

Diante desse processo, surgiram novas áreas agrícolas, que foram incorporadas à produção e ao consumo agropecuário, dinamizando esses novos espaços agrícolas produtivos que servem para a inserção das atividades das cadeias produtivas ${ }^{2}$. A importância que a cadeia produtiva da soja assumiu no cenário agrícola brasileiro ultrapassou os limites das porteiras das fazendas para influir nas discussões sobre pesquisa tecnológica, novas relações territoriais e sociais, competitividade, infraestrutura, etc. Santos e Silveira (2012) já haviam assinalado que a cultura da soja é responsável por inúmeras metamorfoses e especializações produtivas do espaço agrário brasileiro. É, pois, nesse contexto, que se insere, desde o início da década de 1970, o cerrado brasileiro e, na década de 1980, a região

\footnotetext{
Conforme Gonçalves (2005, p. 34-36), essas atividades dividem-se em: (i) pré-porteira - agroindústrias de bens de capital da agricultura, que responde pelo fornecimento dos insumos e equipamentos - agroindústria de fertilizantes, defensivos, sementes, agroindústria de tratores e colheitadeiras, agroindústria de equipamentos de irrigação e armazenamento; (ii) dentro da porteira - agropecuária, que representa o processo biológico de produção, majoritariamente realizado no campo - lavouras permanentes, lavouras temporárias, extrativismo vegetal e animal, criações aquícolas, a pasto e em confinamento; e (iii) pós-porteira - agroindústrias de processamento, agrosserviços da preparação e logística, agrosserviços transacionais (corretoras especializadas em produtos, lobistas e grupos de pressão, corretoras das Bolsas de Mercadorias) e de distribuição (atacadistas, varejistas, empresas exportadoras).

2 No presente texto, optou-se pelo conceito de cadeia produtiva. As cadeias produtivas possuem entre os seus componentes ou subsistemas os diversos sistemas produtivos agropecuários e agroflorestais nos quais ocorre a produção agrícola. Segundo Castro (2002, p. 6-7), "o enfoque de cadeia produtiva provou sua utilidade, para organizar a análise e aumentar a compreensão dos complexos macroprocessos de produção e para se examinar o desempenho desses sistemas, determinar gargalos ao desempenho, oportunidades não exploradas, processos produtivos, gerenciais e tecnológicos. Ao incorporar na metodologia alternativas para análise de diferentes dimensões de desempenho das cadeias produtivas ou de seus componentes individualmente, como a eficiência, qualidade, competitividade, sustentabilidade e a equidade, esta tornou-se capaz de abranger campos sociais, econômicos, biológicos, gerenciais, tecnológicos, o que ampliou possíveis aplicações desse enfoque para um grande número profissionais e de instituições. Entre estas aplicações, aquelas relacionadas com a prospecção tecnológica e não tecnológica”.
} 
do Matopiba e e planície amazônica (DALL' AGNOL, 2008) .

No sul do Maranhão, os resultados da cadeia produtiva da soja são expressivos. $\mathrm{Na}$ safra de 2013/2014, a produção de grãos de soja atingiu 1,6 milhão de toneladas $(20 \%$ do Matopiba), a área plantada alcançou 580 mil hectares, e a produtividade média foi de $2.752 \mathrm{~kg} /$ ha (CONAB, 2015). Entre 2000-2014, o crescimento da produção foi de $430 \%$ e a da área plantada foi de $360 \%$ (CONAB, 2015). Somente no município de Balsas, polo regional, a produção da soja cresceu de 152 mil toneladas, em 2000, para 457 mil toneladas, em 2014 (IBGE, 2015), o que coloca Balsas como terceiro maior município produtor de grãos de soja da região do Matopiba, perdendo apenas para Formosa do Rio Preto (BA) e São Desidério (BA), com quantidade produzida de soja em 2014, respectivamente, de 959 mil e de 720 mil toneladas (IBGE, 2015).

A expansão da cadeia da soja no sul do Maranhão foi objeto de uma variada bibliografia que procurou identificar as principais consequências derivadas dessa expansão nesse território. Em termos gerais, destaca-se que: (i) a modernização da agricultura no sul maranhense resultou no aparecimento de problemas como desemprego urbano elevado e altas taxas de violência (CARNEIRO et al., 2007); (ii) as metamorfoses que ocorreram nos cerrados maranhenses mudaram as relações sociais de produção; os camponeses, pequenos proprietários e agregados perdem acesso aos seus meios de produção, e isso levou-os à ruína (ANDRADE; SOUZA FILHO, 2008); (iii) as transformações introduzidas no mundo do trabalho pela dinâmica da expansão da soja e as novas formas de organização do espaço na região de Balsas (MA) forjam contingentes de trabalhadores excluídos para dar lugar a uma mão de obra mais qualificada (ROCHA FERREIRA, 2008); (iv) as novas dinâmicas socioespaciais introduzidas pelo agronegócio nos cerrados da Bahia, Maranhão, Piauí e Tocantins levaram os trabalhadores a vender sua força de trabalho nas fazendas de soja e instalar-se nas periferias miseráveis nas cidades do agronegócio (ALVES, 2009); (v) uma nova lógica produtiva, no âmbito do trabalho, cria uma estrutura de oportunidade notoriamente excludente nas fronteiras da agricultura moderna no cerrado Norte/Nordeste, gerando descontinuidades e permanências (BENARDES, 2009); (vi) as

\footnotetext{
3 A região do Matopiba é uma delimitação geográfica proposta pelo Grupo de Inteligência Territorial Estratégica (GITE), da Embrapa, que abrange dez mesorregiões e 31 microrregiões homogêneas do IBGE, reunindo um total de 337 municípios nos estados do Maranhão, Tocantins, Piauí e Bahia. Para uma caracterização e uma delimitação precisa dessa área, ver Miranda et al. (2014).

${ }^{4}$ Segundo Espíndola e Cunha (2015, p. 225-226), a expansão da soja para o Centro-Oeste, seguindo em direção ao Nordeste e ao Norte, derivou de múltiplas combinações, entre elas: (i) incentivos fiscais para a abertura de novas áreas para a produção agrícola, no caso a expansão da soja no cerrado está relacionada com os incentivos do Programa Nipo-Brasileiro de Cooperação para o Desenvolvimento do Cerrado (PRODECER); (ii) o estabelecimento de firmas produtoras e processadoras de grãos e de carne nas regiões Centro-Oeste e Nordeste; (iii) baixo valor da terra, se comparado aos preços então praticados na região Sul durante as décadas de 1970 e 1980; (iv) topografia muito favorável à mecanização combinada com as condições climáticas com regime pluviométrico altamente propício ao cultivo de verão; (v) bom nível econômico e tecnológico dos produtores oriundos do Sul do país que ocuparam a região; e (vi) o desenvolvimento de um bem-sucedido conjunto de tecnologias para produção de soja nas áreas tropicais.
} 
dinâmicas territoriais da expansão da fronteira da soja e da organização do trabalho no sul do Maranhão levaram à precarização dos trabalhadores (RODRIGUES, 2013).

Entretanto, em que pese a importância desses trabalhos, as análises, por vezes, acabam por reforçar a preponderância de um fator sobre os outros que causam essas consequências, sem a combinação entre eles, subvalorizando, assim, a divisão social do trabalho. Desse modo, o objetivo central deste texto é apresentar as características territoriais e sociais gestadas na expansão da cadeia produtiva da soja no sul do Maranhão na esteira do aumento da divisão social do trabalho.

Para tanto, utilizar-se-á a categoria de divisão social do trabalho ${ }^{5}$ com base na visão de Rangel $(2005)^{6}$. Esse autor assinala que, em economias não plenamente desenvolvidas e, principalmente, em forte processo de agroindustrialização, não se pode compreender o desenvolvimento pelo simples fato de haver o aumento de insumos e máquinas, e pelos modernos sistemas de produção, mas também pelo fato de a mão de obra (rural) não só trabalhar na produção de bens agrícolas e, além disso, produzir e consumir. Quando essas atividades saem do setor agrícola, consequentemente mudam as condições tecnológicas e, assim, desenvolve-se a economia. Esse descolamento de mão de obra para outras atividades chama-se aumento da divisão do trabalho.

Nesse sentido, na agricultura de escala moderna, as estruturas e estratégias de produção e circulação são, entre outras, pesquisa e desenvolvimento tecnológico (biotecnologia, práticas de manejo, conservação e fertilização de solos, etc.); redução de custos produtivos (mão de obra, maquinário, terceirizações via serviços de especializados); aumento

\footnotetext{
A divisão do trabalho é característica de todas as sociedades conhecidas. A divisão do trabalho dentro de unidades produtivas é peculiar da sociedade capitalista. Assim, Smith (1996) fez uma das primeiras pesquisas que reconheceram importância da divisão do trabalho para o aumento proporcional das forças produtivas do trabalho. O aumento da produção e da produtividade do trabalho, em consequência da divisão do trabalho, segundo Smith (1996, p. 68), ocorre devido a três circunstâncias distintas: (i) maior destreza existente em cada trabalhador; (ii) poupança daquele tempo que, geralmente, seria costume perder ao passar de um tipo de trabalho para outro; e (iii) invenção de um grande número de máquinas que facilitam e abreviam o trabalho, possibilitando a uma única pessoa fazer o trabalho que, de outra forma, teria de ser feito por muitas. Ainda, conforme Smith (1996, p. 73), a divisão do trabalho é a consequência necessária de certa tendência existente na natureza humana à propensão, a intercambiar, a permutar ou a trocar uma coisa pela outra. Por outro lado, Marx (1996, p. 466-472) assinala que a divisão do trabalho constitui a base geral de toda a produção de mercadorias, contudo, faz a seguinte divisão: (i) a divisão do trabalho se expressa como meios de segmentação (emancipação) da sociedade, que é mediada pela compra e venda dos produtos de diferentes ramos de trabalho, ou seja, a divisão do trabalho é o fracionamento dos meios de produção entre muitos produtores de mercadorias independentes entre si; (ii) enquanto a divisão do trabalho, dentro das unidades produtivas, busca a valorização do capital. A divisão do trabalho dentro das unidades produtivas pressupõe concentração dos meios de produção nas mãos de um capitalista e é imposta pelo planejamento, controle e, em consequência, aumenta a produtividade do trabalho e diminui o dispêndio improdutivo da força de trabalho. Nesse sentido, o presente texto dá ênfase maior à divisão do trabalho dentro das empresas agrícolas da cadeia da soja no sul do Maranhão, pois "não é a pura técnica o que nos interessa, mas o consórcio da técnica com as necessidades peculiares do capital" (BRAVERMAN, 1980, p. 74). A escolha dessa categoria de análise tem o interesse de tentar a viabilidade de resgatá-la como uma rica chave de interpretação, no campo da geografia, para a interpretação do Brasil e de suas regiões.

6 Rangel (2005) construiu um arcabouço analítico próprio com base no método dialético e na matriz filosófica do materialismo histórico. Aplicou uma visão de conjunto do processo de desenvolvimento do capitalismo no Brasil, adaptando o materialismo histórico às peculiaridades de uma formação socioespacial complexa brasileira. Ver detalhes em Jabbour (2015).
} 
da competitividade por meio de extrema concorrência, profissionalização na gestão e administração, que também são determinantes para o entendimento da sua expansão (CUNHA, 2015). Ademais, essas estruturas e estratégias mudam de acordo com a temporalidade e a espacialidade onde se desenvolvem em termos combinados e complexos, uma agregação de atraso e dinamismo, ou seja, na luz de múltiplas determinações.?

Partindo dessa escolha analítica, metodologicamente, para a elaboração do texto, optou-se pelo método exploratório-analítico. A abordagem exploratória adota a busca de informações a respeito de certo assunto. As pesquisas exploratórias envolvem levantamento bibliográfico, documental, entrevistas, pesquisas de campo e estudos de caso (GIL, 1994). Operacionalmente, o texto foi desenvolvido com base em parâmetros bibliográficos e documentais, fundamentado em fontes primárias, secundárias e pesquisas de campo de modo contextualizado. Quanto às fontes primárias, recorreu-se a informações e dados dos relatórios da Companhia Nacional de Abastecimento (CONAB), ao banco de dados dos censos do Instituto Brasileiro de Geografia e Estatística (IBGE) e aos relatórios do Sindicato dos Produtores Rurais de Balsas (SindiBalsas). Dentre as fontes secundárias, destacam-se artigos em periódicos indexados, teses, dissertações, livros, sítios de entidades empresariais e governamentais na internet. As pesquisas de campo foram realizadas na cidade de Balsas (MA), em outubro de 2014.

No intuito de sistematização para alcançar o objetivo central proposto, o texto está segmentado em cinco seções, não excetuando esta introdução. A segunda seção trata da entrada da soja às novas características administrativas das empresas agrícolas. $\mathrm{Na}$ terceira, apresentam-se as novas características empresariais e produtivas. Na quarta parte, analisam-se as novas relações territoriais e sociais. E, por último, são apresentadas algumas conclusões acerca do tema em foco.

\section{DA ENTRADA DA SOJA ÀS NOVAS CARACTERÍSTICAS ADMINISTRATIVAS DAS UNIDADES PRODUTIVAS: FAMILIAR E EMPRESARIAL}

A entrada da soja no Maranhão (Figura 1) deu-se no início da década de 1980, em áreas onde houve uma ocupação caracterizada por relações pré-capitalistas e uma pecuária extensiva, que foi ocupando todo o cerrado maranhense (região sul) e em áreas, a partir dos

\footnotetext{
As 'múltiplas determinações' ampliam as possibilidades das análises, pois a realidade é fruto da relação dialética entre os aspectos naturais e humanos. Essas relações são estabelecidas em múltiplas escalas (mundial, nacional, regional e local),e permitem compreender um determinado objeto de estudo num universo mais amplo. As 'múltiplas determinações' de Marx inspiraram as combinações geográficas de Cholley (1964), conforme demonstrou Mamigonian (1965; 1999). As combinações geográficas "podem ser divididas em três grandes categorias: as que resultam, unicamente, da convergência de fatores físicos; aquelas, já mais complexas, que são, a um tempo, de ordem física e de ordem biológica; as mais complicadas e, por isso mesmo, mais interessantes, que resultam da interferência conjunta dos elementos físicos, dos elementos biológicos e dos elementos humanos" (CHOLLEY, 1964, p. 140).
} 
anos 2000, onde existia uma economia monocultora, algodão, e com relações escravistas nos vale dos rios Itapecuru e Munim (região nordeste) (CUNHA, 2015). No sul do território maranhense, com a chegada dos pioneiros ${ }^{8}$ produtores oriundos do Centro-Sul, a partir do início dos anos de 1970, surgiu uma agricultura moderna de arroz e, em seguida, da soja (MALUF, 1977; ANDRADE, 1981).

FIGURA 1 - Áreas produtoras de soja no Maranhão

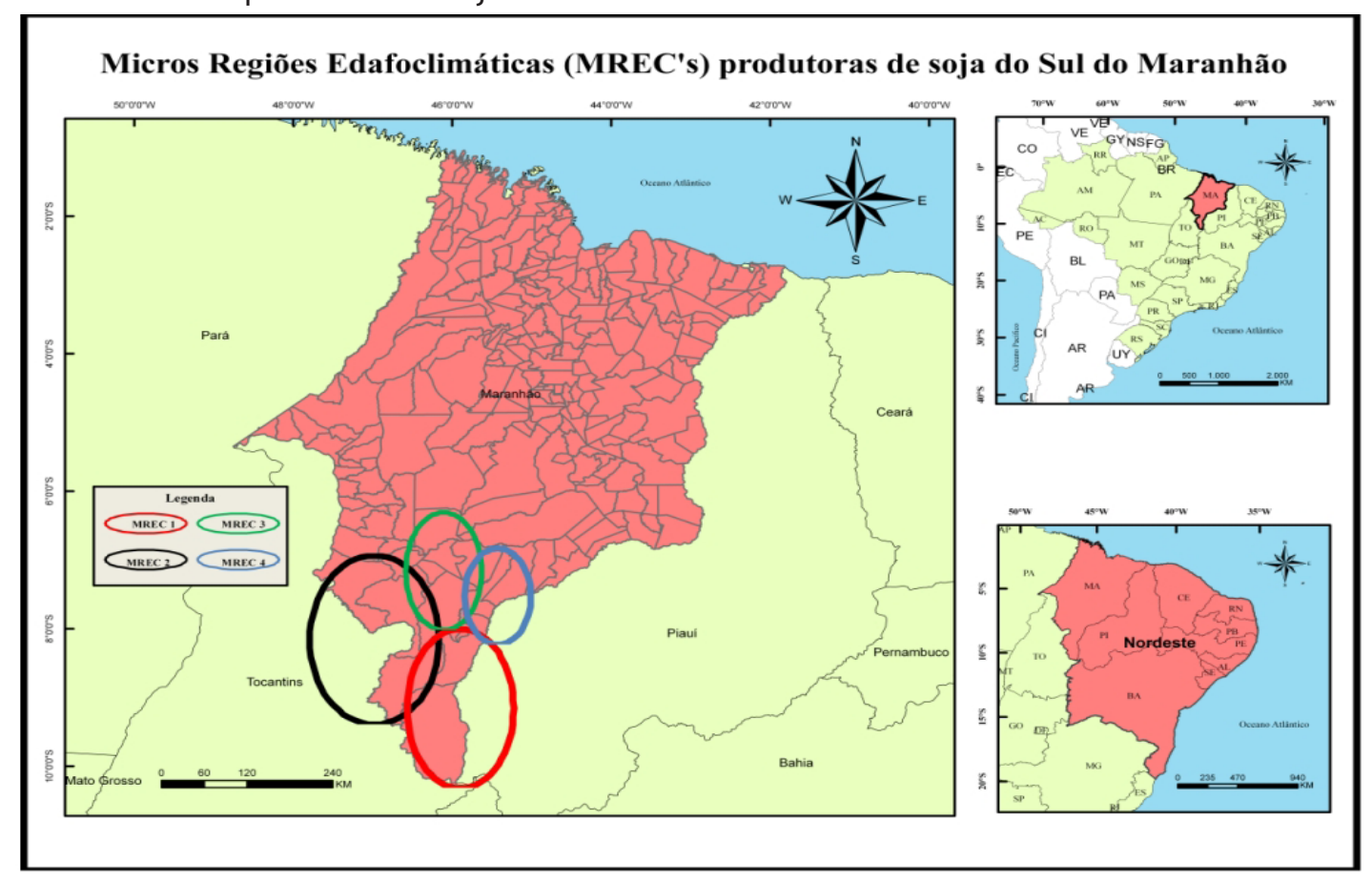

Fonte: Cunha (2015).

O sul maranhense possui 1,8 milhão de hectares (SINDIBALSAS, 2014), propícios para produção em larga escala de grãos. Em 2014, cerca de 580.000 hectares foram utilizados para produzir grãos de soja (IBGE, 2015) e dividem-se em quatro microrregiões edafoclimáticas (MREC) ${ }^{9}$ : MREC 1, Serra do Penitente; MREC 2, Chapada do Gerais de Balsas; MREC 3, Rio Coco; e MREC 4, Ilha de Balsas (Figura 2). Nas MRECs 1 e 2, localizam-se as empresas de origem recente; nas MRECs 3 e 4, estão localizadas, predominantemente, as empresas agrícolas fundadas por pioneiros (CUNHA, 2015).

\footnotetext{
Pioneiros no sentido de Monbeig (1984) e Mamigonian (1965).

9 Kaster e Farias (2012) apontam que, devido à pluralidade de ecossistemas, variedades de solos e clima no Brasil, foram estabelecidas cinco macrorregiões sojícolas (MRS) e vinte regiões edafoclimáticas (REC) distintas para a pesquisa e a indicação de cultivares e épocas de semeadura e colheita. As combinações que determinam as MRSs são latitude (fotoperíodo/temperatura) e regime de chuva, ao passo que as RECs destoam-se por altitude (temperatura) e tipo de solo. Assim sendo, o sul do Maranhão está incluído na MRS 5 e na REC 501. Seguindo, entre outros, esses critérios, Cunha (2015) caracterizou as áreas de plantação de soja no sul maranhense em quatro MRECs. Nessas MRECs, existem doze municípios que produzem soja: (i) na MREC 1, fazem parte os municípios de Balsas, Tasso Fragoso, Alto Parnaíba e Sambaíba; (ii) a MREC 2 contém os municípios de Balsas, Riachão e Carolina; (iii) a MREC 3 contém os municípios de Balsas, Nova Colinas e Fortaleza dos Nogueiras; e (iv) a MREC 4 contém os municípios de Balsas, São Raimundo das Mangabeiras, Loreto, São Domingos do Azeitão e São Felix de Balsas. Vale lembrar que o município de Balsas faz parte das quatro MRECs em virtude de sua grande extensão territorial.
} 
FIGURA 2 - Microrregiões Edafoclimáticas (MRECs) produtoras de soja no sul do Maranhão

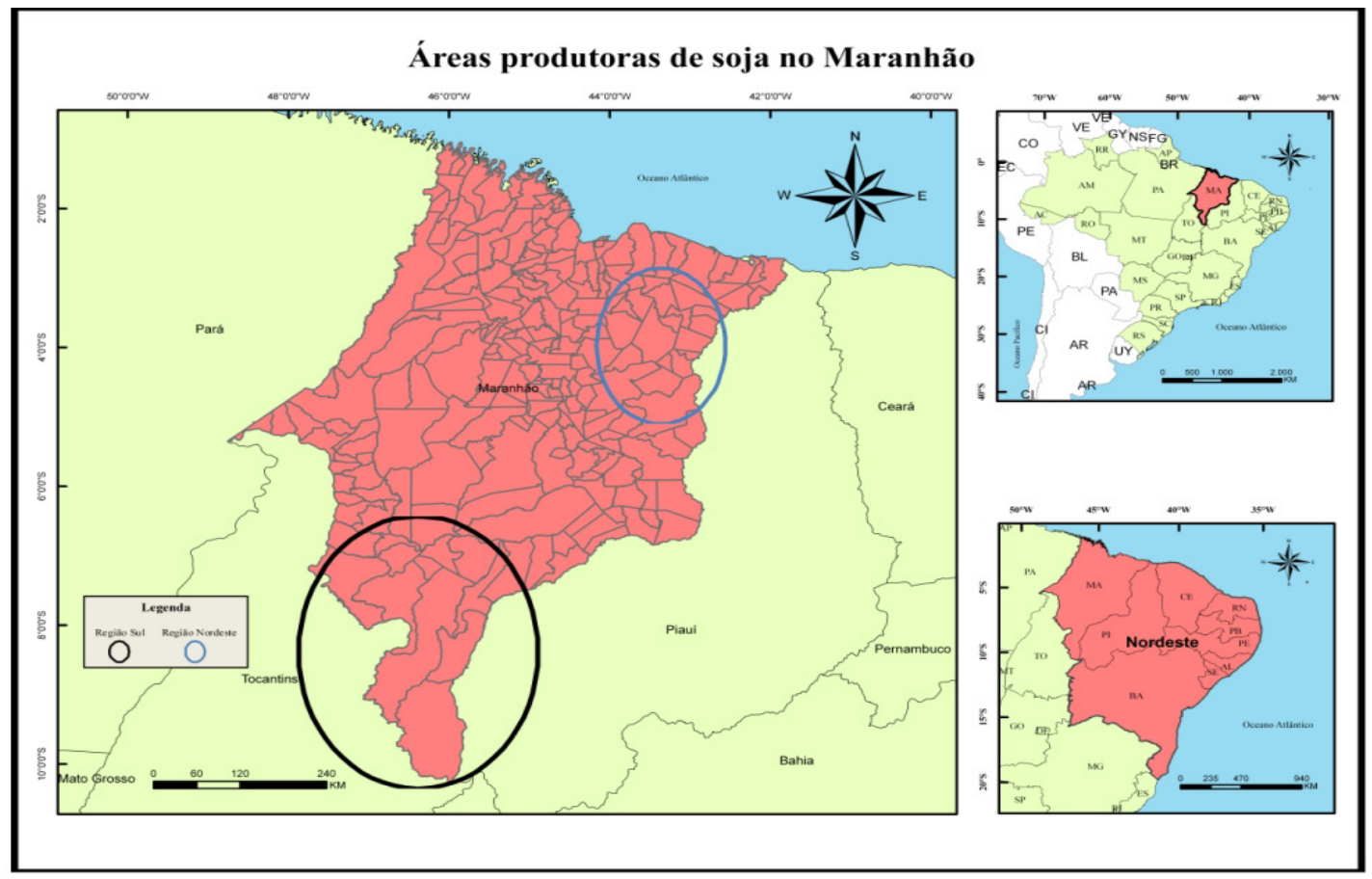

Fonte: Cunha (2015).

De acordo com os dados da Tabela 1, a produção de grãos de soja passou de 55 toneladas, em 1978, para 8.280 toneladas, na safra de 1991, sem aumento significativo da produtividade. Isso porque existiram dois momentos da implantação da soja na região: (i) migrações de produtores sulistas para a cidade de Balsas em busca de terra barata (1972/1990); (ii) chegada de grandes empresas de capitais nacionais (SLC, ABC) e multinacionais (Bunge, Cargill, Louis Dreyfus e Multigrain) a partir de 1990, incorporando inovações tecnológicas, mecanização e utilização de insumos modernos (fertilizantes, adubos e corretivos de solo), além de estratégias de competitividade empresarial e políticas industriais, que foram as responsáveis por esse avanço na produção e na produtividade ${ }^{10}$. A produção aumentou para 2,069 milhões de toneladas, e a produtividade cresceu mais de 50\% entre a safra de 1990/1991 e 2014/2015.

\footnotetext{
${ }^{10}$ Entre esses e outros motivos, explica-se essa amplificação, tanto na produção como na produtividade, por causa da implementação nas plantações comerciais dos resultados da parceria tecnológica entre a Embrapa e a Fundação de Apoio à Pesquisa do Corredor de Exportação Norte Irineu Alcides Bays (FAPCEN). O convênio de transferência tecnológica entre a Embrapa (Embrapa Soja, Embrapa Cerrados) e a FAPCEN teve como objetivo a obtenção de cultivares com alta capacidade de adaptação e alto potencial produtivo, boa qualidade de sementes e resistência às principais pragas e doenças que ocorrem na região. Além do mais, essas parcerias desenvolveram variedades superiores para serem cultivadas e comercializadas pelos produtores de sementes, os quais cooperam no financiamento de parte das pesquisas do programa de melhoramento genético. Dessa parceira, resultaram 36 linhagens de cultivares adaptados à região. Ver detalhes em Cunha (2015).
} 
Tabela 1 - Evolução da área plantada com soja no estado do Maranhão (MA)

\begin{tabular}{ccc|c} 
Safra & Área (ha) & $\begin{array}{c}\text { Quantidade } \\
\text { produzida (t) }\end{array}$ & $\begin{array}{c}\text { Produtividade } \\
\text { (kg/ha) }\end{array}$ \\
\hline $1977 / 1978$ & 32 & 55 & 1.718 \\
\hline $1990 / 1991$ & 4.600 & 8.280 & 1.800 \\
\hline $2000 / 2001$ & 201.000 & 508.620 & 2.530 \\
\hline $2014 / 2015$ & 749.600 & 2.069 .600 & 2.761 \\
\hline
\end{tabular}

Fonte: Conab (2015).

No primeiro momento, os pioneiros mantinham sob total controle (econômico, administrativo, financeiro, etc.) toda a unidade produtiva e acompanhavam tudo de perto, desde a fertilização do solo até as vendas e o embarque da soja nos caminhões. Geralmente, contavam com um ou dois homens de extremada confiança e detinham sobre esses uma dominação econômica, espiritual, moral e física ${ }^{11}{ }^{12}$. De certa forma, apesar do aparente controle das atividades administrativas e produtivas, havia necessidade de saber: Qual o percentual de lucro da última safra? Qual o volume de capital imobilizado na sua empresa agrícola? Qual a produtividade de cada colhedeira? Qual o tipo de georreferenciamento adotado? Qual a quantidade exata de fertilizantes, sementes e defensivos para cada talhão? Qual o melhor terreno na sua área de cultivo? Quais os passivos que mais se depreciam?

Essas questões passavam longe da concepção do agricultor; na maioria das vezes, a contabilidade era feita da seguinte maneira: se sobrou dinheiro para comprar uma caminhonete, é sinal que tudo está funcionando bem ${ }^{13}$. Isso derivava do fato de que os produtores pioneiros não contavam com métodos científicos ${ }^{14}$ e estruturas administrativas e gerenciais modernas nas suas empresas agrícolas. A introdução de maquinário, de novos produtos, novas técnicas e estratégias eram, por vezes, implantações realizadas por intermédio de tateios (erros) e aproximações sucessivas do ideal (acertos). Seus conhecimentos faziam-se por meio do aprendizado pelo uso, pelo senso dos negócios e pela aptidão para inovar.

${ }^{11}$ Informações retiradas das entrevistas realizadas com Antídio Sandri, um dos pioneiros e proprietário do Grupo Fazendas Reunidas e Anthonius Philipsen, filho do pioneiro Leonardus Philipsen, em Balsas (MA), em outubro em outubro de 2014.

${ }^{12}$ Braverman (1980), cujo objetivo é demonstrar o desenvolvimento dos processos de produção e dos processos de trabalho em geral na sociedade capitalista, assinala que o capitalista percebeu o grande potencial no trabalho humano que pode tornar-se disponível por horas estabelecidas, controle sistemático e reorganização do processo produtivo; assim nasce uma gerência primitiva, rígida, despótica. A criação de trabalho livre exigia métodos coercitivos para habituar os empregados às suas tarefas e mantê-los trabalhando durante o dia todo. Braverman (1980) afirma ainda que esses métodos coercitivos foram se eufemismizando com várias legislações e jurisdições no sistema social vigente. As firmas forneciam médicos, professores, capelães, pensões aos pobres, auxílio funeral, etc. com intuito de comandar a vida econômica, espiritual, moral e física dentro ou fora da firma.

${ }^{13}$ Informações retiradas de entrevista realizada com Antídio Sandri, um dos pioneiros e proprietário do Grupo Fazendas Reunidas, em Balsas (MA), em outubro de 2014.

${ }^{14}$ Ver Braverman (1980), que trata da gerência científica. 
A capacidade de inovação traduz-se na modificação das combinações dos fatores de produção, principalmente entre capital e trabalho (SCHUMPETER, 1982). Posto isso, com a chegada de empresas nacionais e multinacionais, a partir dos anos 1990, muitos dos produtores pioneiros evoluíram e passaram a terceirizar atividades de contabilidade, planejamento e gerenciamento, assessoria agronômica, etc., mas mantiveram o controle familiar no comando direto das unidades produtoras. No entanto, outros produtores pioneiros não conseguiram adaptar-se às novas necessidades produtivas e/ou desapareceram ou permaneceram na velha estrutura ${ }^{15}$.

Por consequência, atualmente existe uma diferenciação entre as empresas produtoras de soja: (i) as empresas fundadas pelos pioneiros contratam menos técnicos administrativos e têm uma relação paternalista com os empregados; (ii) as firmas agrícolas de origem recente possuem estrutura de gestão empresarial e incorporam mais mão de obra especializada, como administradores, contadores e outros técnicos.

Essa estrutura geral de administração direta familiar caracteriza as empresas fundadas por pioneiros, como, por exemplo, Fazendas Reunidas, Grupo Francisco Honaiser, Condomínio Agrícola Câmara \& Soldatelli. Essas empresas empregam procedimentos e métodos modestos em todas as etapas do processo produtivo e no comando dos seus trabalhadores. As funções, apesar da hierarquia simples, possuem papéis bem delimitados e práticos. Em geral, os familiares de primeiro grau (esposa, filhos e irmãos) ocupam os cargos de direção; os quadros administrativos são compostos por familiares de segundo e terceiro graus (primos, sobrinhos) e por funcionários antigos e fiéis, que conhecem todo o processo produtivo integrado; e os trabalhadores de campo são considerados "filhos bastardos" e têm como principal característica a multifuncionalidade, quer dizer, dependendo do estágio da produção, um técnico agrícola pode ser, ao mesmo tempo, um tratorista, um balanceiro, etc. As reuniões são praticamente diárias, todo controle passa pelo dono e, conforme os resultados do dia anterior, muda-se de estratégia para melhores práticas de produção e administração.

Além do mais, as inter-relações dessas funções pautam-se por proximidades pessoais nas tratativas, no que diz respeito às tarefas do cotidiano funcionais da empresa. Os gerentes acompanham passo a passo o desenvolvimento das etapas produtivas e corrigem os erros e/ou elogiam os trabalhadores com base na performance de cada um, mantendo uma atmosfera ordeira e controlada, sem chance para possíveis insatisfações coletivas.

Os proprietários costumam, em período de colheita, passar vinte dias seguidos na área

\footnotetext{
${ }^{15}$ Informações extraídas de entrevista realizada com Anthonius Philipsen, filho do pioneiro Leonardus Philipsen, em Balsas (MA), em outubro de 2014.
} 
de plantação, com a finalidade de ficar mais próximos dos trabalhadores e saber de cor o nome de cada um. Essa relação garante um sentimento de gratidão e muitos trabalhadores apadrinham seus filhos ao patrão. Nos períodos de entressafra, alguns trabalhadores são selecionados (conforme o desempenho) para fazer cursos de rotinas administrativas (auxiliares administrativos), reciclagens e atualização (tratoristas, motoristas, balanceiros) dentro ou fora da empresa; outros são selecionados para trabalhar nas casas da família do proprietário. Confraternizações são mensais, e as dinâmicas de grupo são comuns, inclusive com participação do proprietário. Nos finais de ano, ocorrem campeonato de futebol, distribuição de cestas básicas e sorteio de brindes pelas empresas e pelos fornecedores (camisas, boné, copos, talheres, etc.) ${ }^{16}$.

Além disso, a ascensão dentro das empresas tem como base a confiança e a responsabilidade, só assim se pode 'crescer' e chegar a postos mais elevados; esse movimento pode durar anos ${ }^{17}$. Ademais, por serem funções de alta especialização, os serviços de contabilidade, tributação, financeirização e planejamento são todos terceirizados nessas unidades produtivas. A justificativa para isso é o alto custo de instalação dessas atividades no interior da firma. Esses serviços são indispensáveis para a sustentação das empresas, sobretudo para o recolhimento e isenção de impostos, captação de subsídios e financiamentos via bancos oficiais, etc. No caso dos serviços agronômicos, há certa cooperação entre as empresas, pois a mesma consultoria presta serviços para várias firmas simultaneamente.

Por outro lado, as firmas agrícolas de origem recente possuem estrutura de gestão empresarial e incorporam mais mão de obra especializada, como administradores, contadores e outros técnicos. Nas empresas do Grupo Risa e Fazenda Cajueiro, além de em outras, toda a administração e gerenciamento de campo são executados por funcionários especializados, como gestores de administração de agronegócios, técnicos e auxiliares de escritórios, dentre outros, que procuram instalar características gerenciais-profissionaiscientíficas para facilitar decisões e agilizar todas as etapas produtivas. Entretanto, o controle total da empresa não foge das rédeas da família.

Nesse grupo de empresas, há conselhos, que são os órgãos de máxima deliberação. Essa nova forma de estruturar as empresas está relacionada ao desenvolvimento de estratégias de longo prazo, uma maneira de gerenciamento estratégico. Esses conselhos ajudam a avaliar a situação e propor uma reorganização na estrutura operacional e organizacional. Tal modelo corporativo é baseado nos métodos de administração científica, pois as empresas

\footnotetext{
${ }^{16}$ Informações extraídas da entrevista realizada com Isaías Soldatelli, sócio-proprietário do Condomínio Agrícola Câmara \& Soldatelli, em Balsas (MA), em outubro de 2014.

17 Informações extraídas de entrevista realizada com Edson Santos, gerente de campo do Grupo Francisco Honaiser, em Balsas (MA), em outubro de 2014.
} 
perceberam que era preciso contratar equipes enxutas e precisas, com obrigações nítidas e sem improviso, com poder de decisão imediato. Basicamente, essa estrutura é composta por presidente; diretores; gerente geral; e superintendentes de escritórios e de campo. Todavia, esses cargos são ocupados por familiares e empregados de confiança com mais de dez anos de firma e, por isso, dentro das unidades produtivas, as relações com a mão de obra menos qualificada continuam a ser paternalistas.

Para tentar maximizar a eficiência gerencial, essas empresas implementaram programas de gerenciamento e de qualidade total terceirizados. Esse sistema possui instrumentos e dispositivos ${ }^{18}$ capazes de monitorar e controlar os processos produtivos e administrativos, visando - em curto, médio e longo prazo - à melhoria da competitividade, à ampliação máxima da produtividade do trabalho, à prevenção de perdas e à identificação prévia de pontos de expansão e contração. Cursos de qualificação e reciclagem são obrigatórios para todas as funções, pois, por meio deles, busca-se eficácia total na gestão empresarial.

Ainda assim, esse grupo de empresas internalizou os serviços de tributação, contabilização, financeirização, consultoria agronômica e planejamento. Essas atividades no seio das empresas funcionam como uma unidade de negócios na qual se desenvolvem estratégias de planejamento e execução para evidenciar políticas de alto rendimento e efetiva atuação na comercialização, principalmente com as grandes tradings, e capitação de recursos via empréstimos ${ }^{19}$.

Diante disso, há uma combinação de dois padrões de estruturas administrativas nas empresas agrícolas no sul do Maranhão. No que concerne ao controle direto por familiares, essas empresas apresentam: os empregados, tanto de escritório como de campo, com sentimento de gratidão e apadrinhamentos de filhos aos patrões; os trabalhadores de campo com multifunções, dependendo do estágio da cultura; pouca rotação de cargos superiores; os gerentes, como líderes e, ao mesmo tempo, companheiros dos trabalhadores; confraternizações e um ambiente harmônico; e as relações assemelham-se a características paternalistas e senhoris. Segundo Wilkinson (2009), isso tudo gera pontos negativos e baixa competitividade nas empresas familiares: falta de planejamento, precária formação profissional dos familiares, conflitos de interesses nos herdeiros, perda de capital investido da firma pelos familiares e parentes em favor próprio, favorecimento de parentes e agregados sem qualificação necessária para vagas de emprego.

\footnotetext{
${ }^{18}$ Essas ferramentas dividem-se em: internamente (1) sistema eletrônico de ponto e pagamento, (2) ginástica laboral, (3) monitoramento de áudio e vídeo das atividades, (4) sistema de comunicação via intranet e rádio, (5) acompanhamento psicológico para funcionários, (6) treinamento sistemático para todas as funções, (7) bafômetros; e externamente (8) implantação do sistema de nota fiscal eletrônica, (9) agendamento eletrônico dos fornecedores, (10) compras programadas.

${ }^{19}$ Informações extraídas de entrevista realizada com José Gorgen, presidente do grupo RISA, em Balsas (MA), em outubro de 2014.
} 
Por outro lado, há empresas que têm uma organização empresarial, mesmo com o controle nas mãos de familiares e parentes, e possuem processos administrativos e produtivos comandados por técnicos profissionais, uma departamentalização bem definida, programas de qualidade total e a procura sistemática e efetiva em aprendizado e qualificação. Ainda conforme Wilkinson (2009), a busca pela máxima profissionalização é um dos desafios que se impõem às empresas agrícolas que estão interessadas em crescer, buscar formas de financiar a obtenção de novas atividades e, inclusive, reorganizar suas dívidas, bastante convergida atualmente no curto prazo, pois as grandes tradings são agressivas e competitivas, uma vez que contam com poderoso staff executivo, fácil acesso ao capital e com capacidades para oferecer produtos e serviços a preços mais baixos.

A responsabilidade do gerenciamento, tanto na produção como na administração de uma empresa agrícola, consiste em estar atento em longo prazo (medidas estratégicas) e de forma interligada aos ciclos dos sistemas produtivos de safras. Gerenciar a produção de uma fazenda moderna estrategicamente é estruturar da melhor maneira possível as ações operacionais para que ela seja sustentável ao longo das flutuações de mercado, dos ataques dos concorrentes e das ofertas de produtos e insumos.

Em termos mais amplos, uma produção pautada na eficiência deve conhecer a repercussão de suas atitudes sobre as etapas operacionais (curto prazo), pois deve dominar novas tecnologias e manter controle sobre o domínio da técnica e das operações intrafirma (CUNHA, 2015). Dessa forma, a correta alocação dos recursos, o planejamento da produção ao longo do ano e o dimensionamento do volume da produção a ser estocado poderão viabilizar ou não o negócio. Quando são investigados os motivos do bom ou do mau desempenho de uma empresa agrícola, estes estão muito além de sua infraestrutura física e de sua capacidade produtiva ociosa ou não. Assim sendo, o administrador de uma fazenda de soja, implicado com os resultados positivos da empresa, deve manter-se atento ao mercado de grãos e estar em constante busca de bens e serviços de melhor qualidade para suas necessidades ao menor custo. Com isso, o objetivo essencial na aplicação de métodos científicos nas empresas agrícolas é produzir mercadorias mais baratas.

\section{AS NOVAS CARACTERÍSTICAS TERRITORIAIS, PRODUTIVAS E EMPRESARIAIS}

Anteriormente, afirmou-se que as empresas agrícolas têm controle familiar, mas se diferenciam por possuírem ou não uma departamentalização profissional. Contudo, isso não significa que há uma diferenciação nas estruturas das unidades produtivas. 
Na verdade, a distinção ocorre apenas em quantificação de máquinas ${ }^{20}$, implementos, edificações e mão de obra.

Conforme assinalou Rangel (2005), a indústria é para a agricultura uma fornecedora de tecnologia para as inovações nas atividades agrárias. Com incorporação de tecnologia no campo, foi possível o aumento da divisão do trabalho, o que proporcionou trabalhadores braçais e trabalhadores qualificados, especializações dos instrumentos e ferramentas. Consequentemente, a agricultura é para a indústria uma solicitante de inovações em produto que passam a ser inovações em processo nas atividades agrícolas tendo em vista aumento de produtividade; produção em escala; ganhos financeiros e econômicos; possibilidades de exploração em diversos tipos de áreas pequenas, grandes, planas e acidentadas, baixa e alta fertilidade, etc.; e o acirramento da concorrência intercapitalista.

As tecnologias utilizadas nas diversas atividades da agricultura no Brasil estabeleceram novas concepções e geraram cadeias produtivas que não são mais elucidadas pela velha bifurcação campo-cidade (rural e urbano). Partindo dessas concepções, Gonçalves (2005, p. 10) ressalta que,

[...] com o capital dos agronegócios tomando a forma de capital geral, movimentando-se no processo de acumulação no seu ímpeto de valorização, foram consolidados segmentos e ramos de produção para atuarem de forma exclusiva com a agropecuária tanto a montante como a jusante. A emancipação de atividades antes internas às propriedades rurais, que passaram a se constituir em novos ramos das cadeias de produção, fiz a agropecuária perder espaço relativo no complexo produtivo dos agronegócios da agricultura. Nesse processo em que cada vez mais a produção passou a ser cada vez menos "fruto da terra e do trabalho do homem", na acepção bíblica cristã, não apenas o trabalho foi potencializado e perdeu espaço para a mecanização e automação, mas também a terra perdeu espaço para a fertilização, correção e genética que impulsionaram a produtividade da terra. A agricultura moderna pode ser feita com menos terra e menos trabalho, mas com muito mais capital, estando inserida na lógica de expansão da reprodução ampliada do capital.

Com a introdução de máquinas e implementos na agricultura, mudaram radicalmente as técnicas de produção, assim como o engajamento de mão de obra na produção agrícola, pois os ganhos de produtividade levaram à modificação do homem nessa atividade, possibilitando o acesso a modernas práticas de produção na agricultura.

A esse respeito, as empresas agrícolas produtoras de soja no sul maranhense são essencialmente poupadoras de mão de obra, pois, quanto maior é a área plantada, maior é a relação da massa de meios de produção (capital constante) com a massa de trabalho empregado (capital variável). Ou seja, há um aumento da composição orgânica do capital,

\footnotetext{
${ }^{20}$ Cabe lembrar que na agricultura, mesmo com todo o avanço e desenvolvimento das máquinas agrícolas, há alguns empecilhos nas adaptações aos mais diversos terrenos. A máquina na indústria é posta em um lugar artificial, criado exclusivamente para ela. Na agricultura, a máquina trabalha na natureza e sua adaptação vai depender do grau de exploração das atividades agrícolas. Ver mais detalhes em Kautsky (1980).
} 
pois, no regime de produção capitalista, as máquinas não são para poupar trabalho, mas sim para realizar economia de salários.

No grupo das empresas fundadas por pioneiros (3.000 hectares em média), o número de hectares por funcionário, em média, está no patamar de 65. Nos períodos de colheita, contrata-se em média 25 trabalhadores, divididos em tratoristas, motoristas, balanceiros, mecânicos, cozinheiros, auxiliares de campo e auxiliares de colheita (sazonal-temporário). As jornadas de trabalho são realizadas em um turno diário de oito horas, havendo, na época da colheita, horas extras ${ }^{21}$.

No grupo de empresas agrícolas de origem recente, que possuem, em média, dez mil hectare ${ }^{22}$ em diversas unidades de campo, há aproximadamente um funcionário para cada cem hectares e, nas épocas de safra, contrata-se temporariamente cerca de vinte pessoas. Entre os funcionários fixos, estão agrônomos, técnicos agrícolas, engenheiros mecânicos, químicos, administradores e contadores, técnicos de informática, motoristas, tratoristas, cozinheiros, operários de campo, auxiliares de escritórios, etc. As jornadas de trabalho são em turno único, de dez horas diárias (sendo oito horas normais e duas horas extras) ${ }^{23}$. Essa reduzida quantidade de trabalhadores decorre da implementação de maquinaria e ferramentas que possuem a tendência de aumento da força produtiva de trabalho e máxima negação do trabalho necessário, pois o trabalhador aparece como supérfluo desde que sua ação não seja condicionada pelas necessidades do capital (MARX, 2011).

Cabe lembrar que, mesmo com o conteúdo tecnológico por trás, a soja é uma commodity, um produto estandardizado, com margem pequena de valor adicionado, e que só gera lucro se for produzida em escala. Assim, a diferenciação das firmas está no ininterrupto investimento em equipamentos e maquinaria. Quando se fala em incremento de equipamentos e maquinário (progresso técnico), que aparecem na forma de capital fixo, faz-se crescer a composição orgânica do capital, que causa, mais rapidamente, acréscimo na acumulação e na reprodução do capital. Essa situação gera diferenças nas taxas de lucros e acirra as concorrências, e, consequentemente, os capitalistas menores são incorporados pelos maiores. Ou seja, o sistema capitalista é caracterizado pelo aumento crescente do capital na produção, tal como por acréscimo progressivo na centralização da propriedade do capital social, que Marx (2011) assinalou como centralização do capital.

\footnotetext{
${ }^{21}$ Informações retiradas de entrevista realizada com Francisco Honaiser, um dos pioneiros e proprietário do Grupo Honaiser em Balsas (MA), realizada em Balsas (MA), em outubro de 2014.

22 Segundo Lenin (1982), a extensão da área está longe de indicar sempre e de uma forma direta a grandeza efetiva da exploração e seu caráter capitalista. De acordo com o autor, é o trabalho assalariado o indicador mais representativo do capitalismo na agricultura. E, em consequência, o crescimento do emprego de mão de obra assalariada acirra a contradição de classe.

${ }^{23}$ Informações retiradas de entrevista realizada com José Gorgen, proprietário do Grupo RISA, em Balsas (MA), realizada em Balsas (MA), em outubro de 2014.
} 
Dessa feita, para execução das atividades referentes ao sistema de produção de soja no sul do Maranhão, as empresas fundadas por pioneiros possuem estruturas de equipamentos e maquinário ${ }^{24}$ diferente apenas na quantidade, potência e idade (equipamentos adquiridos seminovos), em relação às empresas agrícolas de origem recente.

$\mathrm{Na}$ caracterização seguinte, em termos gerais, enquadram-se as fazendas fundadas por pioneiros, em virtude da homogeneização progressiva das estruturas produtivas na agricultura moderna. Para execução das etapas dos sistemas produtivos da cadeia produtiva de soja, a frota de tratores é composta (em média) de cinco unidades. Um deles é usado em operações de baixa potência e distância, como no transporte de fertilizantes, geradores, peças, etc. Outros quatros tratores, dois deles equipados com piloto automático, são de potência média de $130 \mathrm{cv}$ a $180 \mathrm{cv}$ e executam tarefas, como, por exemplo, plantio, preparação do solo, pulverização, distribuição interna de fertilizantes e equipamentos mais pesados.

No portfólio maquinário, existem (em média) três plantadeiras, que adubam e plantam ao mesmo tempo, com vinte linhas, com elementos de soja, milho e algodão, com distribuidor de sementes a vácuo e com tanque sementeiro com capacidade de 1.700 $\mathrm{kg}$, espaçamento de $40 \mathrm{~cm}$ a $90 \mathrm{~cm}$ e caixa de adubo de $4.800 \mathrm{~kg}$ de capacidade máxima. Há também um pulverizador com barra de pulverização hidráulica de 24 metros de comprimento, equipado com sistema GPS para gerenciamento da área de aplicação, que evita até $90 \%$ das sobreposições de áreas, além de controladores automáticos de pressão e fluxo dos bicos pulverizadores, com tanque de defensivos de 2.270 litros. Entre o maquinário, também há duas colheitadeiras, com tanque graneleiro de 6.750 litros, sensor de nível e com tubo de descarga com capacidade de 78 litros por segundo ${ }^{25}$.

As unidades produtivas contam ainda com veículos para transportes: (i) sendo, no caso dos externos (insumos, ferramentas, alimentos, peças, etc.), um caminhão; e (ii) três camionetes para transportes internos (dos barracões aos talhões), de sementes, ferramentas, etc. Para o acondicionamento dos insumos e materiais, há dois galpões: (i) um armazena fertilizantes e defensivos, onde há diversos misturadores, adubadoras a lanço e equipamentos de preparo e secagem: (ii) outro armazena e trata as sementes. Na sede, há espaço para um miniescritório, uma oficina para reparos em máquinas e prolongamento da vida útil de ferramentas, uma garagem para as máquinas, amplo refeitório, área de balança, alojamentos e uma casa para os empregados. Há ainda um silo com capacidade estática de aproximadamente dez mil toneladas.

\footnotetext{
${ }^{24}$ No que diz respeito à evolução tecnológica das máquinas agrícolas, à padronização, à tendência de investimento em eletrônica embarcada e ao aumento da capacidade e tamanho, ver Fonseca (1990) e Sarti et al. (2009).

${ }^{25}$ Informações extraídas de entrevistas com gerentes de campo e engenheiros das fazendas realizadas em Balsas (MA), em outubro de 2014.
} 
Em média, fazendas com essas estruturas têm uma produção entre 15 e 25 mil toneladas por safra de soja. Com o excelente nível tecnológico dos equipamentos e máquinas em tais fazendas, que proporcionam ganhos em escala, há uma capacidade ociosa de $35 \%{ }^{26}$, que é amenizada com a locação para os grandes produtores da região e para produtores em outras áreas em período entre safras.

Nas empresas agrícolas de origem recente, na parte meridional maranhense, como dito, além de as áreas cultivadas serem maiores, os insumos e a maquinaria são mais numerosos, mais potentes e com idade de uso menor do que as empresas agrícolas fundadas por pioneiros. Há uma padronização maior nas estruturas de produção, pois as diferenças estão, apenas, na órbita de marca e modelos dos equipamentos e no arranjamento das estruturas imóveis das fazendas.

Partindo disso, considera-se válida a caracterização das instalações para representar o grupo de empresas agrícolas de origem recente. Na realização dos estágios do processo produtivo da soja, as fazendas dispõem, nos portfólios, de três máquinas colheitadeiras modelo com plataforma de trinta pés, com sistema de molinete sincronizado com a velocidade da colheitadeira e acionamento hidráulico. Essas máquinas possuem mecanismo de separação e debulha com dois rotores que possibilitam baixíssima porcentagem de quebra de grãos e com um potente ventilador com fluxo de ar que garante a limpeza eficiente dos grãos. O picador de palha é regulável e deixa uma cobertura ideal para o plantio direto. O tanque graneleiro tem capacidade de 11.110 litros, e o tubo de descarga é de 110 litros/ por segundo ${ }^{27}$.

A frota de tratores é composta (em média) por nove máquinas, variando de 110 a $280 \mathrm{cv}$ de potência. Seis tratores são exclusivos para grande escala de produção e atuam, principalmente, no plantio com alto rendimento, fazendo parte do conjunto completo com as plantadeiras (quatro unidades) de 36 linhas, com espaçamento ajustável, embarcado, de $35 \mathrm{~cm}$ a $50 \mathrm{~cm}$ em cada linha. O trator planta a vácuo e tem a capacidade de $3.200 \mathrm{~kg}$ de sementes, com produtividade de 200 hectares por dia cada conjunto. Os defensivos são aplicados com três pulverizadores do modelo SP 3500, com barra de pulverização de 27 metros, com bitolagem hidráulica e sistema de mapeamento eletrônico, que aplica a quantidade certa de defensivo em cada área atacada e evita passar por uma mesma área já trabalhada. O reservatório de produtos comporta 3.500 litros $^{28}$.

${ }^{26}$ Informações extraídas de entrevistas com gerentes de campo e engenheiros das fazendas realizadas em Balsas (MA), em outubro de 2014.

${ }^{27}$ Informações extraídas de entrevistas com gerentes de campo e engenheiros das fazendas, realizadas em Balsas (MA), em outubro de 2014.

${ }^{28}$ Informações extraídas de entrevistas com gerentes de campo e engenheiros das fazendas, realizadas em Balsas (MA), em outubro de 2014. 
A logística interna e externa conta com dois caminhões e duas caminhonetes. Geralmente há quatro galpões: um serve de garagem da frota, com uma ampla oficina; um é para armazenagem de fertilizantes e defensivos; um é para acondicionamento de sementes; e um é para guardar ferramentas menores. Há, em média, três silos com capacidade para trinta mil toneladas de grãos, com controle automático de temperatura e umidade, e área de secagem dos grãos. Nas sedes das fazendas, há um escritório para os técnicos da produção (agrônomos, químicos e mecânicos), que acompanham em tempo real todos os dados das etapas produtivas, uma verdadeira estação de geoprocessamento. Há outro escritório de trabalhos financeiros, tributários e contábeis. Há, ainda, auditórios, grandes refeitórios e diversas lanchonetes, área de balança, alojamento para empregados e visitantes, e vilas de casas para moradores/funcionários permanentes, barbearias, salas de costura (serviços de costureira), áreas de convivência e recreação. Existem placas sobre normas de segurança do trabalho e é obrigatório o uso de equipamentos de proteção individual (EPIs).

Essas estruturas, combinadas com as condições naturais, proporcionam uma produção entre 35 e 50 mil toneladas de grãos soja em cada safra ${ }^{29}$. A agricultura moderna de escala apresenta especificidades em todos os seus processos produtivos. No Brasil, as regiões produtoras de soja diferenciam-se nas estratégias de produção, pois cada uma apresenta necessidades discrepantes uma da outra, como luminosidades (luz solar), solos e seus nutrientes, temperatura, umidade, relevo, etc. A tecnologia, nas últimas décadas, foi um determinante fundamental para o sucesso da agricultura no país; para os avanços na biotecnologia, genética e, principalmente, para a criação de sementes modificadas. Entretanto, as condições naturais constituem, ainda, elemento fundamental da produtividade agrícola e da produtividade do trabalho. Com isso, a combinação entre desenvolvimento tecnológico, evolução econômica e social, e características naturais de cada região é fundamental para se entender os sistemas de produção agrícola.

\section{AS NOVAS RELAÇÕES TERRITORIAIS E SOCIAIS}

O sul maranhense foi ocupado por vaqueiros baianos que ultrapassaram inicialmente o rio São Francisco e depois o rio Parnaíba e desenvolveram uma estrutura econômica e social baseada na pecuária extensiva com relações de produção feudais ${ }^{30}$. Com a chegada

${ }^{29}$ Informações extraídas de entrevistas com gerentes de campo e engenheiros das fazendas, realizadas em Balsas (MA), em outubro de 2014.

${ }^{30}$ Segundo Cunha (2015), o gado e a lavoura eram de propriedade do senhor de engenho. O crescimento dos rebanhos gerou a incompatibilidade entre as duas culturas e a separação da propriedade agrícola da propriedade pastoril. Entrementes, o gado ainda era de propriedade do senhor de engenho. A total diferenciação das duas culturas, a expansão geográfica do interior - da Bahia ao Maranhão - tornou-se necessária, pois as trocas internas entres as áreas pastoris e áreas agrícolas e áreas mineradoras se intensificaram. A propriedade da terra se expandiu e gerou relações feudais de produção pela sua incompatibilidade nas relações escravistas. Isso fica evidenciado no fator preponderante: o sistema de remuneração. A relação de produção era que a cada quatro crias, uma era do dirigente do estabelecimento (em média 250 cabeças de gado/ano), o vaqueiro. Somente em cinco anos 
dos produtores oriundos do Centro-Sul do país, no início da década de 1970, aliada a combinações geoeconômicas, começou uma agricultura de arroz mecanizada, com relações capitalistas em concomitância com relações pré-capitalistas. Andrade e Souza Filho (2008, p. 201) afirmam que ocorreram mudanças significativas nas relações sociais de produção. Camponeses instalados há várias gerações, pequenos proprietários e agregados perdem acesso aos seus meios de produção. Os autores (2008, p. 204) assinalam ainda que esses são constituintes de uma nova camada em formação - os assalariados - e que isso impossibilita qualquer tipo de acumulação, ou seja, causa sua ruína.

Sem embargo do trabalho dos autores, Lênin (1982, p. 16) sublinha o contrário:

[...] a liberação de uma parte dos produtores dos meios de produção subentende, necessariamente, a passagem desses meios para outras mãos, sua conversão em capital, e que, por consequência, os novos proprietários desses meios produzirão sob a forma de mercadorias os produtos que, anteriormente, eram consumidos pelo próprio produtor - vale dizer: ampliam o mercado interno. Esquecem que a ampliação da produção pelos possuidores dos meios de produção coloca no mercado novas demandas de instrumentos, de matérias-primas, de meios de transporte etc., bem como de artigos de consumo (seu enriquecimento acarreta naturalmente o aumento do seu consumo). Para o mercado, o que importa não é o bem-estar do produtor, mas os seus meios pecuniários disponíveis; o declínio do bem-estar de um camponês patriarcal, que antes praticam uma economia predominantemente natural, é perfeitamente compatível com o aumento do volume de recursos pecuniários em suas mãos, pois quanto mais esse camponês se arruína mais é forçado a recorrer à venda de sua força de trabalho e tanto maior é a parte dos meios de subsistência (mesmo que sejam o mais exíguos) que ele deve adquirir no mercado.

Com a penetração da agricultura do arroz, em que a maioria dos usineiros eram, também, grandes comerciantes e proprietários de grandes fazendas pastoris (MALUF, 1977), as relações de produção evoluíram e acentuaram-se as relações capitalistas (ANDRADE, 1981). No entanto, mesmo com o aprofundamento das relações sociais de produção capitalista com a ingressão da cadeia produtiva da soja, houve poucas mudanças significativas na estrutura da região sul maranhense no âmbito da concentração da propriedade privada da terra.

No que diz respeito à estrutura fundiária do sul do Maranhão, há um fato pitoresco. $\mathrm{Na}$ Tabela 2, observa-se que o número de estabelecimentos de até cem hectares correspondia,

recebia sua parte acumulada, ou seja, recebia uma grande quantidade de uma só vez, o que lhe dava condições de ser seu próprio patrão. Formou-se uma estrutura econômica e social apoiada em forças produtivas ligado à pecuária e as relações de produção eram apoiadas em um conjunto de renda trabalho e renda produto. Rangel (2005) assinala que essa estrutura desenvolveu um caráter conservador da classe dominante que usava métodos de dominação extra-econômicos. Entretanto, isso não impediu o avanço do processo de industrialização no Brasil, porém, foi uma condição essencial de uma modernização conservadora e com exclusão social. "O Brasil empreendeu sua industrialização sem previamente remodelar as relações de produção na agricultura. Daí resulta que, acima das contradições internas de seu setor capitalista (entre trabalho e capital) e do seu setor feudal (entre o latifúndio feudal e o servo da gleba), paire a contradição entre o seu lado moderno e o seu lado arcaico. A economia brasileira é, ao mesmo tempo, moderna e arcaica e a coexistência entre seu lado moderno e o arcaico não se exprime por uma simples justaposição, mas por um conflito que enche toda a nossa história. A unidade entre esses dois aspectos é uma unidade dialética, uma unidade de contrários" (RANGEL, 2005, p. 574) 
em 1975, a 74,6\% do total, e a área, no mesmo ano, era de 1,55\%. Já em 2006, esse mesmo grupo representava $59,42 \%$ do total de estabelecimentos, e a área aumentou para 3,14\%. No grupo entre 500 a 1.000 hectares, manteve-se inalterada a participação em termos de superfície, apesar de diminuir a participação no número dos estabelecimentos. Essa diminuição é explicada pela concentração da propriedade privada, que elimina os estabelecimentos menos capitalizados e menos competitivos, quer dizer, a pequena exploração só triunfa onde a agricultura deixa de ser lucrativa.

Em 2006, o IBGE mudou a classificação dos grupos e só é possível fazer uma comparação com os estabelecimentos acima de 1000 ha. Em 1975, o número de estabelecimentos e a área desse grupo eram, respectivamente, 5,55\% e 61,94\%; por outro lado, em 2006, nesse mesmo grupo, as taxas eram de 6,07\% e 70,91\%. Portanto, ao contrário do que normalmente se divulga, não ocorreram mudanças significativas na concentração da propriedade privada da terra com o advento da cadeia produtiva da soja, e essa estrutura fundiária só pode ser explicada levando em consideração as características da agricultura brasileira, no âmbito do desenvolvimento do capitalismo na agricultura com seu processo de centralização da propriedade privada no campo. Lênin (1981, p. 103-105) explica que,

[...] na agricultura, toda a terra (nos países civilizados) está ocupada, e a superfície das fazendas só pode se ampliar mediante a centralização de várias parcelas e, mais ainda, de modo que constituam uma superfície contínua. Compreende-se que a ampliação de uma fazenda mediante a compra das parcelas vizinhas é muito difícil, sobretudo porque as parcelas pequenas estão ocupadas em parte por operários agrícolas (indispensáveis ao grande agricultor) e em parte por pequenos camponeses que dominam a arte de manter-se em suas terras mediante uma redução de seu consumo até um mínimo incrível. [...] Ampliar uma fazenda comprando terras vizinhas não é tão fácil como ampliar uma fábrica construindo novos corpos de edifícios para um número adicional de máquinas etc. [...] Trata-se dos latifúndios, da acumulação de várias fazendas numa mesma mão. A estatística costuma ter em conta somente as fazendas, e não nos oferece dados sobre o processo de concentração de distintas fazendas nas mãos de grandes latifundiários. [...] Cuja consequência é uma forma peculiar e superior de grande exploração agrícola capitalista, na qual várias grandes fazendas se fusionam, constituindo uma unidade econômica regida por um órgão central.

Tabela 2 - Estrutura fundiária do sul do Maranhão entre 1975-2006

\begin{tabular}{|c|c|c|c|c|c|c|c|c|c|c|c|c|c|c|}
\hline \multirow{3}{*}{ Ano } & \multicolumn{12}{|c|}{ Área (em ha) e número de estabelecimentos } & \multirow{2}{*}{\multicolumn{2}{|c|}{ Total }} \\
\hline & \multicolumn{2}{|c|}{ Até de 100} & \multicolumn{2}{|c|}{$\begin{array}{c}\text { De } 100 \text { até } \\
500\end{array}$} & \multicolumn{2}{|c|}{$\begin{array}{c}\text { De } 501 \text { até } \\
1.000\end{array}$} & \multicolumn{2}{|c|}{$\begin{array}{c}\text { De } 1.001 \text { até } \\
5.000\end{array}$} & \multicolumn{2}{|c|}{$\begin{array}{c}\text { De } 5.001 \\
\text { até } 10.000\end{array}$} & \multicolumn{2}{|c|}{$\begin{array}{c}\text { Mais de } \\
10.000\end{array}$} & & \\
\hline & Área & $\mathrm{N}$ & Área & $N$ & Área & $N$ & Área & $N$ & Área & $\mathrm{N}$ & Área & $N$ & Área & $\mathrm{N}$ \\
\hline 1975 & 6480 & 1426 & 58848 & 242 & 93389 & 136 & 164176 & 94 & 51968 & 8 & 42143 & 4 & 417004 & 1910 \\
\hline 1985 & 8888 & 2900 & 62669 & 292 & 71215 & 109 & 201874 & 103 & 74544 & 12 & 43992 & 3 & 463182 & 3419 \\
\hline 1995 & 20318 & 808 & 98650 & 557 & 78072 & 98 & 105697 & 58 & 9700 & 1 & 38000 & 2 & 350437 & 1524 \\
\hline 2006 & 19736 & 959 & 93294 & 455 & 69837 & 102 & - & - & - & - & - & - & 628665 & 1614 \\
\hline
\end{tabular}

Fonte: IBGE $(1975 ; 1985 ; 1995 ; 2006)$.

Nota: em 2006, o IBGE usou as classificações de 1000 a 2500 ha (número de estabelecimentos de 1000 ha foi 61 e área, em hectare, foi 8.4647) e mais de 2.500 ha (número de estabelecimentos foi 37 e área, em hectare, foi 361.151). 
Com isso, pode-se afirmar que, mesmo com o avanço da cadeia produtiva da soja no cerrado maranhense, permanece a pequena propriedade ao lado da grande propriedade (empresas agrícolas), pois na região as terras sempre foram de uso da agricultura extensiva. Ao mesmo tempo, há no sul do Maranhão produtores que possuem terras em todos os estados do Matopiba. Muitos têm uma única pessoa jurídica, registrada em Balsas (MA), e outros possuem uma pessoa jurídica em cada estado. Segundo dados da Tabela 3, no sul do Maranhão verificou-se, em 2014, 256 produtores filiados ao Sindicato dos Produtores Rurais, havendo um total de 432 propriedades, com uma maioria possuindo até 5.000 hectares, representando 580 mil hectares. Há dois produtores que possuem cinquenta mil hectares cada um, distribuídos em vários municípios e com única central de administração. Fica evidente a existência de uma centralização da propriedade privada da terra, ou seja, há congregação de diferentes propriedades em uma só mão e/ou família.

Tabela 3 - Números de propriedades, condição do produtor e área total de soja no sul do Maranhão

\begin{tabular}{c|c|c|c|c}
$\begin{array}{c}\text { Números de } \\
\text { propriedades }\end{array}$ & $\begin{array}{c}\text { Números de } \\
\text { produtores }\end{array}$ & $\begin{array}{c}\text { Números de } \\
\text { proprietários }\end{array}$ & $\begin{array}{c}\text { Números de } \\
\text { arrendatários }\end{array}$ & $\begin{array}{c}\text { Total de área } \\
\text { (em ha) }\end{array}$ \\
\hline 432 & 256 & 207 & 49 & 580.000 \\
\hline
\end{tabular}

Fonte: Sindibalsas (2014) e IBGE (2015).

Em referência à condição dos produtores relativamente às propriedades, o número de arrendamentos é pouco significativo, representando 19\% dos produtores. Os proprietários representam a grande maioria, $81 \%^{31}$. Segundo Kautsky (1980), em regiões onde prevalece o domínio da exploração por parte do próprio dono, em que propriedade e exploração misturam-se, a inclinação para centralização apresenta-se não mais como simples aumento do estabelecimento, mas pelo desejo de adquirir nova propriedade.

Assim sendo, como assinalou Rangel (2005), o Brasil não passou por uma reforma agrária, que os muitos "estudiosos radicais" afirmavam que seria um elemento fundamental para nossa industrialização. Ao contrário, os trabalhadores, tanto urbanos como rurais, foram sendo afastados de seu berço familiar e, quase em totalidade, foram sendo lançados ao mercado sem chance de regresso. Em outros termos, a população que reside no campo vai se tornando escassa, migrando para as cidades e, consequentemente, as cidades vão se tornando superpopulosas por causa da expulsão da mão de obra do campo com a chegada da indústria moderna na agricultura.

${ }^{31}$ Informações extraídas de entrevista realizada com Valdir Zaltron, presidente do Sindicado dos Produtores Rurais de Balsas (MA), em outubro de 2014. 
Pode-se falar que a evolução das estruturas e das relações de trabalho no sul do Maranhão - da pecuária extensiva à cultura da soja - foi resultante do aumento sistemático de fases da divisão social do trabalho, o que levou a uma especialização e à transformação de produtores em proletários. Os avanços da divisão do trabalho e a expulsão que salientava Rangel (2005) tinham sido diagnosticados por Lênin (1982), quando ele analisou, por diferenças técnicas, as três formas básicas da indústria ${ }^{32}$. Assim afirma Lênin (1982, p. 342-343):

A pequena produção mercantil se caracteriza por uma técnica extremamente primitiva, fundada no trabalho manual e inalterável quase desde tempos imemoriais. O produtor permanece um camponês, a quem a tradição capacitou para assimilar procedimentos de transformação de matérias-primas. Com a manufatura, surge a divisão do trabalho, que provoca importantíssimas transformações técnicas e converte o camponês em artesão, em "operário produtor de peças". Mas a produção manual persiste, e por isso, o progresso dos métodos de produção é muito lento. A divisão do trabalho aparece espontaneamente e, como o trabalho camponês, transmite-se pela tradição. Uma mudança radical só é possível com a grande indústria mecanizada: ela joga fora a habilidade manual, reorganiza a produção sobre bases racionais e utiliza sistematicamente as conquistas da ciência. Enquanto o capitalismo não organizou entre nós a grande indústria mecanizada, nos ramos ainda não afetados pela grande indústria observamos uma estagnação quase total da técnica, o emprego do mesmo torno manual, do mesmo moinho de água ou vento que há um século se empregavam na produção. [...] A grande indústria mecanizada só pode se desenvolver aos saltos, numa sucessão de períodos em que a prosperidade se alterna com as crises. Esse crescimento em saltos da fábrica intensifica enormemente a ruína dos pequenos produtores; a fábrica ou atrai massas de operários na época da febre de produção, ou os dispensa. A formação de um exército de reserva de desempregados, dispostos a aceitar qualquer trabalho, toma-se uma das condições da existência e do desenvolvimento da grande indústria mecanizada. [...] A "instabilidade" da grande indústria mecanizada sempre provocou, e continua a provocar, queixas reacionárias daqueles que continuam a ver as coisas com os olhos do pequeno produtor e se esquecem de que só essa "instabilidade" substitui a antiga estagnação por uma veloz transformação dos métodos de produção e de todas as relações sociais. Um dos aspectos dessa transformação é a separação entre a indústria e a agricultura, a libertação das relações sociais na indústria das tradições servis e patriarcais que continuam pesando sobre a agricultura.

\footnotetext{
${ }^{32}$ Essas três formas básicas de indústrias são: (i) pequena produção mercantil basicamente camponesa; (ii) manufatura capitalista; (iii) e grande indústria mecanizada. Em termos gerais, a propensão fundamental do processo de desenvolvimento é a transformação da pequena produção mercantil em produção capitalista, mediada pela formação da manufatura. E esta se metamorfoseia em grande indústria mecanizada. Esse processo, guardadas as particularidades da sua formação socioespacial, está claramente evidenciado, no sul do Maranhão, na transformação da "roça de toco" estritamente camponesa e em combinação com pecuária de subsistência ("não roça"), ou praticamente seu desaparecimento, em produção e usinagem de arroz e depois na agricultura moderna da soja, como demonstraram Maluf (1977), Andrade (1981), Andrade e Souza Filho (2008) e Cunha (2015).
} 
Essa análise foi desenvolvida por Lenin (1982) quando do estudo da realidade russa pré-revolução. Contudo, é possível fazer uma analogia com o sul do Maranhão, pois, no caso específico da moderna produção de soja no referido local/lugar, encontra-se um setor de assalariados combinados, simultaneamente, com a continuação do patriarcalismo entre o empresário agrícola e os trabalhadores assalariados.

$\mathrm{Na}$ composição dos trabalhadores assalariados da produção de soja no sul do Maranhão, o que predomina são os trabalhadores permanentes regidos pela Consolidação das Leis do Trabalho (CLT) e, em menor grau, os terceirizados e os horistas, contratados temporariamente para serviços pontuais em épocas de semeadura e colheita da produção. Nas MRECs, ocorrem diferenciações no percentual de trabalhadores permanentes, terceirizados e temporários. Nas MRECs 1 e 2, são praticamente nulas as terceirizações, pois as empresas agrícolas possuem departamentos de planejamento, contabilidade e tributação e de agricultura de precisão, além de possuírem o menor número de permanentes e maior de temporários, devido a mais alta mecanização e às áreas maiores de cultivo. As MRECs 3 e 4 possuem maior número de permanentes e menor número de contratados, pois a taxa de mecanização acontece em menor escala (menor número de máquinas e equipamentos de menor porte) e há significativas terceirizações, pois as empresas agrícolas não possuem departamentos de planejamento, contabilidade e tributação e de agricultura de precisão. Segundo cálculo aproximado do SindiBalsas ${ }^{33}$, a porcentagem da mão de obra no cultivo do soja no sul do Maranhão é: (i) 70\% de trabalhadores permanentes; (ii) 20\% de trabalhadores contratados em regime horista nos períodos de plantio e colheita; e (iii) $10 \%$ de terceirizados pelas empresas agrícolas.

Em termos de disponibilidade de contratação de mão de obra para as atividades produtivas da soja, há deficits em relação a profissionais de nível superior (agrônomos, engenheiros mecânicos, gestores de agronegócios, contadores, biólogos, etc.), técnicos (agrícolas, agrimensores, georreferenciadores, etc.) e a maioria é de fora do estado. As contratações de operadores de máquinas e técnicos de campo (balanceiros, mecânicos, etc.) são facilitadas, pois geralmente há ascensão na própria empresa, as revendedoras de máquinas e implementos facilitam cursos e reciclagem, e a maioria pertence ao ambiente rural do sul do Maranhão. Também existe diálogo permanente entre o SindiBalsas, o Sindicato dos Trabalhadores e Trabalhadoras Rurais de Balsas (STTR), a Associação dos Trabalhadores Rurais de Balsas (ATRB) e a Federação dos Trabalhadores e Trabalhadoras na Agricultura do Estado do Maranhão (FETAEMA), para preenchimentos de vagas disponíveis.

${ }^{33}$ Informações extraídas de entrevista realizada com Valdir Zaltron, presidente do Sindicado dos Produtores Rurais de Balsas (MA), em outubro de 2014. 
Na sindicalização, há uma diferenciação nas MRECs. Os trabalhadores de menor escolaridade (nativos do sul maranhense) são sindicalizados por meio do STTR e exercem suas atividades fundamentalmente nas MRECs 3 e 4 . Os trabalhadores de maior escolaridade são filiados na ATRB e trabalham, em sua maioria, nas MRECs 1 e 2. O STTR é uma entidade (tradicional) filiada à FETAEMA e à Confederação Nacional dos Trabalhadores na Agricultura (CONTAG). A ATRB é uma entidade bem recente e aparelhada pelo SindiBalsas. Em termos gerais, o nível de sindicalização é muito baixo, em torno de $8 \%{ }^{34}$.

Essa baixa sindicalização da mão de obra da cadeia produtiva da soja no sul do Maranhão remete a dois motivos: (i) os filhos dos trabalhadores rurais estão desprendidos do meio rural em que foram criados, buscando cada vez mais as cidades, pois não querem ter a vida bucólica que tiveram seus avós e pais, e são cada vez mais cidadãos do mundo ${ }^{35}$; e (ii) os índices de absenteísmo e alcoolismo são relativamente significativos, fazendo com que os empregadores agrícolas tenham uma maior aproximação dos empregados, oferecendo, na própria empresa, serviços médicos e de psicologia, gerando sentimento de gratidão e, por consequência, apadrinhamentos. A atuação predominante do STTR restringe-se aos trabalhadores rurais tradicionais e nas comunidades mais afastadas, atuando como um mero auxiliador em aposentadoria rural. Pelo assinalado, afirma-se que há ainda relações patriarcais, e as entidades classistas não são compatíveis com o novo tempo da agricultura moderna.

\section{CONCLUSÕES}

No desenvolvimento do processo de produção, o trabalho, as funções e o sistema organizativo foram, os poucos, sendo dominados por grupos de gerentes e administradores, que aplicavam métodos científicos aos diversos níveis de uma unidade produtiva, seja ela industrial, agrícola ou comercial (BRAVERMAN, 1980).

A responsabilidade de um gerenciamento, tanto na produção como na administração de uma empresa agrícola, consiste em estar atento em longo prazo (medidas estratégicas), de forma interligada, aos ciclos dos sistemas produtivos de safras. Gerenciar a produção de uma fazenda moderna estrategicamente é estruturar da melhor maneira possível as

${ }^{34}$ Informações extraídas de entrevista realizada com Abraão Morais, presidente do Sindicado dos Trabalhadores e Trabalhadoras Rurais de Balsas (MA), em outubro de 2014.

${ }^{35}$ Os trabalhadores sentem a necessidade inconsciente de pretensão ao consumo exacerbado, e isso deturpa a visão cosmopolita, suprime o comportamento rebelde e acalma a personalidade. Os homens trabalhadores sabem que não adianta imaginar riquezas das casas dos ricos, mas eles aspiram a tais riquezas e pelo menos querem alcançar bens e serviços que tornam suas vidas com mais dignidade. Ver mais detalhes em Santos (2013). 
ações operacionais para que ela seja sustentável ao longo das flutuações de mercado, dos ataques dos concorrentes e das ofertas de produtos e insumos. Em termos mais amplos, uma produção pautada na eficiência deve conhecer a repercussão de suas atitudes sobre as etapas operacionais (curto prazo), pois deve dominar novas tecnologias e manter controle sobre o domínio da técnica e das operações intra-firma.

Com isso, o objetivo essencial na aplicação de métodos científicos nas empresas agrícolas é produzir produtos o mais barato possível, obter a maximização dos lucros, unificar os trabalhos de administração e minimizar os gastos dos recursos disponíveis, aumentando a produtividade do trabalho com o aproveitamento das características mais adequadas dos funcionários. Desse modo, chega-se, então, ao desenvolvimento pleno da divisão social do trabalho, usufruindo dos interesses de mercado, explorando as diversidades edafoclimáticas e explorando as condições econômicas e sociais de cada área.

Constatou-se, então, que a estrutura administrativa das unidades produtivas da cadeia de produção da soja no sul do Maranhão tem uma diferenciação geral: nas MRECs 3 e 4, onde predominam as fazendas dos pioneiros, a produção é menor e incorpora-se menos mão de obra especializada; e nas MRECs 1 e 2, onde se localizam, em sua maioria, as fazendas das empresas de origem recente, estas são as mais produtoras, possuem gestão empresarial e contratam mais trabalhadores especializados. Entretanto, ambos os grupos de empresas são administrados por controle familiar direto.

Levando em conta a evolução das estruturas econômicas e sociais, mostrou-se que, com o surgimento da cadeia produtiva da soja, não houve mudança expressiva na estrutura fundiária do sul do Maranhão e que está ocorrendo um processo de centralização das terras por via de novas propriedades. Com o avanço da moderna agricultura brasileira, as empresas agrícolas foram estimuladas a aderir à modernização e à mecanização de suas lavouras. As estruturas de maquinário das empresas agrícolas diferem-se somente na potência, quantidade e na idade dos equipamentos, máquinas, tratores e colheitadeiras.

Ademais, as empresas fundadas por pioneiros mantêm relações paternalistas para evitar qualquer tipo de irresignação coletiva. Nas empresas de origem recente, a estrutura empresarial faz com que as equipes de trabalho sejam reduzidas, e as relações paternalistas são impostas aos trabalhadores menos qualificados. Há uma cooperação entre os sindicatos patronais e de trabalhadores rurais no espoco de contratações de empregados. Contudo, o nível de sindicalização é muito baixo. Entre outros motivos, o pequeno nível de sindicalização se dá por falta de adaptação das entidades sindicais com a plataforma da agricultura moderna. 
As estruturas administrativas, produtivas e as relações territoriais e sociais representam interação entre o novo e o velho, com domínio do primeiro. Porém, esse poder de dominação do novo não se realiza completamente. Vale lembrar que não se pode cair em determinismos específicos: pois pode gerar vocação (SANTOS, 1977). Cada momento do processo histórico de desenvolvimento, com sua estrutura econômica, social, política, cultural, dentro de uma formação socioespacial, tem uma significação particular. Por isso, como foi demonstrado, numa sociedade determinada "não tem funções permanente, nem um nível de forças produtivas fixos e relações de produção e de propriedade imutáveis. Interagem e evolui no processo" (SANTOS, 1977, p. 84).

Por fim, é fato que divisão social do trabalho é a condição motriz para o desenvolvimento de uma determinada formação socioespacial, porque oferece à sociedade condições para aumentar seu domínio sobre a natureza, para obter recursos e meios para satisfação de suas necessidades (RANGEL, 2005). Ressalta-se ainda que, derivada do aumento dessa condição motriz, a modernização da agricultura nos anos de 1970 gerou novos segmentos produtivos a jusante e a montante da agricultura, bem como criou uma geração de agricultores (pequenos, médios e grandes), que passou a se orientar por uma racionalidade técnica em busca da produtividade do capital (GONÇALVES, 2005).

\section{REFERÊNCIAS}

1. ALVES, V. E. L. As novas dinâmicas socioespaciais introduzidas pelo agronegócio nos cerrados da Bahia, Maranhão, Piauí e Tocantins. In: BERNARDES, Júlia Adão; BRANDÃO, José Bertoldo (Org.). A territorialidade do capital (Geografias da Soja II). Rio de Janeiro: Arquimedes Edições, 2009.

2. ANDRADE, M. de P. Os gaúchos descobrem o Brasil. 1981. 156f. Dissertação (Mestrado)Faculdade de Filosofia, Letras e Ciências Humanas - FFLCH, Universidade de São Paulo USP, São Paulo, 1981.

3. ANDRADE, M. de P.; SOUZA FILHO, B. (Org.). Os gaúchos descobrem o Brasil: projetos agropecuários contra a agricultura camponesa. São Luis: Edufma, 2008.

4. BERNARDES, J. A. Fronteiras da agricultura moderna no cerrado Norte/Nordeste: descontinuidades e permanências. In: BERNARDES, Júlia Adão; BRANDÃO, José Bertoldo (Org.). A territorialidade do capital (Geografias da Soja II). Rio de Janeiro: Arquimedes Edições, 2009.

5. BRAVERMAN, H. Trabalho e capital monopolista: a degradação do trabalho no século XX. 3. ed. Rio de Janeiro: Zahar, 1980.

6. CARNEIRO, M. S. et al. A 'modernização' da agricultura no Sul Maranhense: um balanço 30 anos depois. 2007. (impresso) 
7. CASTRO, Antônio Maria Gomes de. Cadeia produtiva: marco conceitual para apoiar a prospecção tecnológica. In: SIMPÓSIO DE GESTÃO DA INOVAÇÃO TECNOLÓGICA, 22., 2002, Salvador. Anais... Salvador: Fieb, 2002. v. 1, p. 1-14.

8. CHOLLEY, A. Observações sobre alguns pontos de vista geográficos. Boletim Geográfico, Rio de Janeiro, IBGE, n. 179-180, p. 139-145, 1964.

9. CONAB. Companhia Nacional de Abastecimento. Séries históricas de produção de grãos. Brasília: 2014a. Disponível em: <http://www.conab.gov.br/>. Acesso em: 10 jan. 2015.

10. CUNHA, R. C. C. Gênese e dinâmica da cadeia produtiva da soja no Sul do Maranhão. 2015. 180 f. Dissertação (Mestrado)- Curso de Geografia, Geociências, Universidade Federal de Santa Catarina - UFSC, Florianópolis, 2015.

11. DALL' AGNOL, A. Soja: o fenômeno brasileiro. Londrina: EMBRAPA, 2008.

12. ESPÍNDOLA, C. J.; CUNHA, R. C. C. A dinâmica geoeconômica recente da cadeia produtiva de soja no Brasil e no Mundo. Geotextos, v. 11, n. 1, p. 217-238, Salvador, UFBA, 2015.

13. FONSECA, M. G. D. Concorrência e progresso técnico na indústria de máquinas para agricultura: um estudo sobre trajetórias tecnológicas. 1990. 249 f. Tese (Doutorado em Economia)- Instituto de Economia, Universidade Campinas, Campinas, 1990.

14. GIL, A. C. Métodos e técnicas de pesquisa social. Atlas: São Paulo, 1994.

15. GONÇALVES, J.S. Agricultura sob a égide do capital financeiro: passo rumo ao aprofundamento do desenvolvimento dos agronegócios. Informações Econômicas, São Paulo, IEA, v. 35, p. 7-36, abr. 2005.

16. IBGE. Instituto Brasileiro de Geografia e Estatística. Censos Agropecuários: 1975; 1980; 1985; 1995; 2006. Disponível em: <http://www.sidra.ibge.gov.br >. Acesso em: 10 ago. 2015.

17. IBGE. Instituto Brasileiro de Geografia e Estatística. Censos: 2000; 2010. Disponível em: $<$ http://www.sidra.ibge.gov.br >. Acesso em: 10 ago. 2015.

18. IBGE. Instituto Brasileiro de Geografia e Estatística. Produção agrícola municipal - 2014. 2015. Disponível em: <http://www.sidra.ibge.gov.br >. Acesso em: 11 ago. 2015.

19. JABBOUR, E. M. K. Ignácio Rangel e suas influências intelectuais. In: ENCONTRO NACIONAL DE ECONOMIA POLÍTICA, 20, 2015, Foz do Iguaçu. Anais... Foz do Iguaçu: UNILA, 2015. v. 1, p. 1-20.

20. KASTER, M.; FARIAS, J. R. B. Regionalização dos testes de valor de cultivo e uso e da indicação de cultivares de soja: terceira aproximação. Londrina: Embrapa Soja, 2012. 70 p. (Documentos, 330).

21. KAUTSKY, K. A questão agrária. 3. ed. São Paulo: Proposta Editorial, 1980.

22. LENIN, V. O Capitalismo na Agricultura: o livro de Kautsky e o artigo do senhor Bulgákov. In:

23. SILVA, J. G. da; STOLCKE, V. (Org.). A Questão Agrária. São Paulo: Brasiliense, 1981.

24. __ Desenvolvimento do capitalismo na Rússia: o processo de formação do mercado interno para a grande indústria. Rio de Janeiro: Editora Abril, 1982. 
25. MALUF, R. S. J. A expansão do capitalismo no campo: o arroz no Maranhão. 1977. 142 f. Dissertação (Mestrado em Economia)- Instituto de Economia, Unicamp, Campinas, 1977.

26. MAMIGONIAN, A. Estudo geográfico das indústrias de Blumenau. Revista Brasileira de Geografia, Rio de Janeiro, v. 27, n. 3, p. 387-481, jul./set., 1965.

27. ___ Kondratieff, ciclos médios e organização do espaço. Geosul, n. 28, v. 14, Florianópolis, UFSC, 1999.

28. MARX, K. Grundrisse. Manuscritos econômicos de 1857-1858: esboços da crítica da economia política. São Paulo: Boitempo, 2011.

29. ______ O capital: crítica da economia política. São Paulo: Nova Cultural, 1996. (Os Economistas). Disponível em: <http://www.histedbr.fe.unicamp.br/acer_fontes/acer_marx/ ocapital-2.pdf $>$. Acesso em: 20 set. 2015.

30. MIRANDA, E. de. et al., Proposta de delimitação territorial do Matopiba. Nota Técnica, Campinas, GITE/EMBRAPA, n. 1, maio 2014. Disponível em: <http://www.embrapa.br/gite/ publicacoes/NT1 >. Acesso em: 10 ago. 2014.

31. MONBEIG, P. Pioneiros e fazendeiros de São Paulo. 2. ed. Coleção Geografia: Teoria e Realidade. São Paulo: Hucitec, 1984.

32. RANGEL, I. Obras reunidas. v. 1. Rio de Janeiro: Contraponto, 2005.

33. RODRIGUES, S. J. D. Dinâmicas territoriais da expansão da fronteira da soja e da organização do trabalho no sul do Maranhão. CAMPO-TERRITÓRIO: Revista de Geografia Agrária, v. 9, n. 17, p. 86-110, Uberlândia, UFU, 2014.

34. ROCHA FERREIRA, M. da G. A dinâmica da expansão da soja e as novas formas de organização do espaço na Região de Balsas - MA. 2008. 272 f. Tese (Doutorado em Geografia)Instituto de Geociências, Universidade Federal do Rio de Janeiro - UFRJ, Rio de Janeiro, 2008.

35. SAMPAIO, F.; MEDEIROS, M.; BROIETTI, M. Dinâmica capitalista na agricultura brasileira: acumulação e relações de trabalho. Cadernos Geográficos, Florianópolis, CFH/UFSC, n. 11, 2005.

36. SANTOS, M. O espaço da cidadania e outras reflexões. Brasília: Fundação Ulysses Guimarães, 2013.

37. Sociedade e espaço: A formação social como teoria e como método. Boletim Paulista de Geografia, São Paulo, v. 54, p. 81-100, jun. 1977.

38. SANTOS, M.; SILVEIRA, M. L. O Brasil: território e sociedade no início do século XXI. 16. ed. Rio de Janeiro: Record. 2012.

39. SARTI, F.; SABBATINI, R.; VIAN, C. E. F. Perspectivas do investimento em Mecânica. Projeto PIB. 2009. Disponível em: <http://www.bndes.gov.br/SiteBNDES/export/sites/default/bndes_ pt/Galerias/Arquivos/empresa/pesquisa/pib/pib_mecanica.pdf>. Acesso em: 10 jan. 2015.

40. SCHUMPETER, J. A. Teoria do desenvolvimento econômico. São Paulo: Abril Cultural, 1982 (Os Economistas).

41. SINDIBALSAS. Relatório anual 2014. Balsas: Sindibalsas, 2014. 
42. SMITH, A. Investigação sobre a natureza e causas da riqueza das nações. São Paulo: Nova Cultural, 1996. (Os Economistas). Disponível em: < http://www.afoiceeomartelo.com.br/ posfsa/Autores/Smith,\%20Adam/A\%20Riqueza\%20das\%20Na\%C3\%A7\%C3\%B5ees,\%20 Investiga $\% \mathrm{C} 3 \% \mathrm{~A} 7 \% \mathrm{C} 3 \% \mathrm{~A} 30 \% 20$ Sobre\%20Sua\%20Natureza\%20e\%20Suas\%20Causas\%20 -\%20Vol.\%20I.pdf>. Acesso em: 19 set. 2015.

43. WILKINSON, J. (Coord.). Perspectivas do investimento no agronegócio. Rio de Janeiro: UFRJ, Instituto de Economia, 2009. Disponível em: <http://www.projetopib.org/?p=documentos $>$. Acesso em: 13 jan. 2015.

Artigo recebido em 15 de outubro de 2015.

Artigo aceito em 3 de dezembro de 2015. 